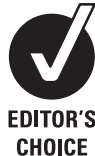

CHOICE

\title{
The groin triangle: a patho-anatomical approach to the diagnosis of chronic groin pain in athletes
}

\author{
E C Falvey, ${ }^{1,2}$ A Franklyn-Miller, ${ }^{2}$ P R McCrory ${ }^{1}$
}

${ }^{1}$ Centre for Health, Exercise and Sports Medicine, School of Physiotherapy, Faculty of Medicine, Dentistry and Health Sciences, The University of Melbourne, Victoria, Australia; ${ }^{2}$ Olympic Park Sports Medicine Centre, Melbourne, Australia

Correspondence to:

Dr E C Falvey, Sports Surgery

Clinic, Santry Demesne, Dublin

9, Ireland; e.falvey@mac.com

Accepted 6 March 2008

Published Online First

16 November 2008

\section{ABSTRACT}

Chronic groin pain is a common presentation in sports medicine. It is most often a problem in those sports that involve kicking and twisting movements while running. The morbidity of groin pain should not be underestimated, ranking behind only fracture and anterior cruciate ligament reconstruction in terms of time out of training and play. Due to the insidious onset and course of pathology in the groin region it commonly presents with well-established pathology. Without a clear clinical/pathological diagnosis, the subsequent management of chronic groin pain is difficult. The combination of complex anatomy, variability of presentation and the non-specific nature of the signs and symptoms make the diagnostic process problematical. This paper proposes a novel educational model based on patho-anatomical concepts. Anatomical reference points were selected to form a triangle, which provides the discriminative power to restrict the differential diagnosis and form the basis of ensuing investigation. This paper forms part of a series addressing the three-dimensional nature of proximal lower limb pathology. The $3 \mathrm{G}$ approach (groin, gluteal and greater trochanter triangles) acknowledges this, permitting the clinician to move throughout the region, considering pathologies appropriately.

Chronic groin pain is a common presentation in sports medicine practice. Studies in professional sports have found groin injury to be the fourth most common injury affecting soccer players, ${ }^{1}$ the third most common injury in Australian rules football ${ }^{2}$ and it also has a high prevalence in ice hockey ${ }^{3}$ and rugby. ${ }^{4}$

This gives an incomplete portrayal, however, as the morbidity attached to chronic groin pain means it is behind only fracture and joint reconstruction in terms of lost time from injury. ${ }^{45}$

All these sports involve kicking and twisting movements while running. These actions place a strain on fascial and musculoskeletal structures that are fixed to a number of bony anatomical points in close proximity. The resultant tissue damage and/or entrapment of anatomical structures may cause pain

This paper sets out a method based on pathoanatomical principles for a systematic examination of the chronically painful groin, which enables the clinician to discriminate more easily between pathological conditions and target their investigation and subsequent management to specific diagnoses.

\section{THE GROIN TRIANGLE}

The specific anatomical landmarks and borders of the groin triangle are set out in fig 1 .
APEX POINTS OF THE GROIN TRIANGLE

The anatomical apex points of the triangle are as follows: the anterior superior iliac spine (ASIS); the pubic tubercle and the 3G (groin, gluteal and greater trochanter triangles) point.

\section{The $3 \mathrm{G}$ point}

From anthropometric measurements, the authors defined a new reference point at the apex of the triangle. This point was termed the "3G point" in reference to the three-dimensional pathology and the groin, gluteal and greater trochanteric regions. The relationship of this point in the anterior coronal plane was the mid-distance point between the ASIS and the superior pole of the patella, and in the posterior coronal plane double the distance from the spinous process of the L5 lumbar vertebrae to the ischial tuberosity in the line of the femur.

\section{ANATOMICAL RELATIONS OF THE BORDERS OF THE GROIN TRIANGLE}

\section{Superior border of the groin triangle}

The line between the pubic tubercle and the ASIS forms the superior border of the triangle. This corresponds to the anatomical position of the inguinal ligament, a thickening of the aponeurosis of the external oblique muscle. Superior to this line, working from the pubic tubercle medially to the ASIS laterally the following structures will be encountered: the rectus abdominis and rectus abdominis sheath insertions; internal oblique, external oblique and transversus abdominis insertions and aponeuroses; inguinal canal, medially the superficial inguinal ring and conjoint tendon, more laterally the canal and further laterally the deep inguinal ring; the ilioinguinal, iliohypogastric and genital branch of the genitofemoral nerve; the conjoint tendon of ilio-psoas as it passes under the lateral third of the inguinal ligament; the visceral contents of the abdomen and pelvis.

The insertion of the rectus abdominis and its sheath are intimately related to the aponeuroses of the obliques and transversus abdominis. The junction of where these structures converge at the pubic bone revolves around the inguinal canal. The internal inguinal ring is located at a point between the mid-inguinal point (situated midway between the anterior superior iliac spine and the pubic symphysis) and the midpoint of the inguinal ligament. ${ }^{6}$ The transversalis fascia and the conjoint tendon, a confluence of internal oblique and transversalis fasciae, form the posterior wall of the canal. The superficial inguinal ring, the opening in the external oblique aponeurosis is situated a 


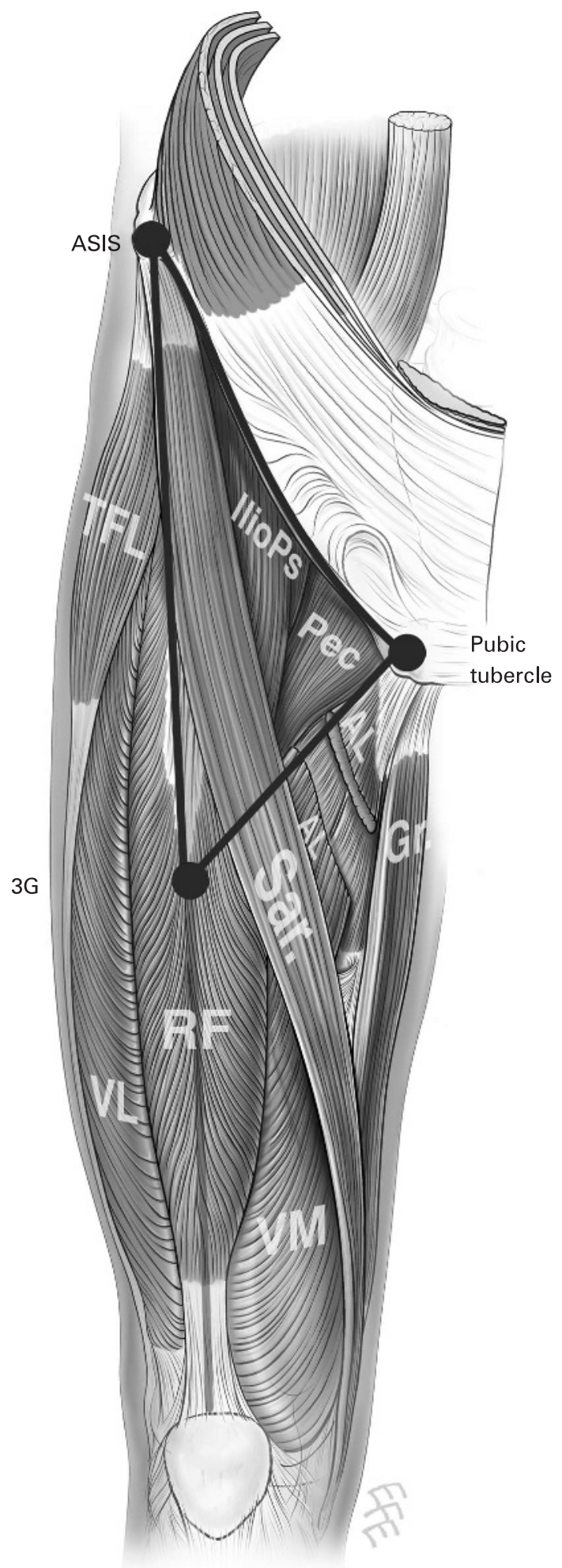

Figure 1 The groin triangle. AL, adductor longus; $A S I S$, anterior superior liac spine; Gr, gracilis; llioPS, iliopsoas; Pec, pectinius; RF, rectus femoris; Sar, sartorius; TFL, tensor fasciae latae; $3 G$, the $3 G$ point; $\mathrm{VL}$, vastus lateralis; VM, vastus medialis.

centimetre above and lateral to the pubic tubercle. The anatomy of the ilioinguinal and iliohypogastric and genital branch of the genitofemoral nerves is extremely variable, between them they supply the skin of the lower abdomen, medial thigh and scrotum. ${ }^{\text {? }}$

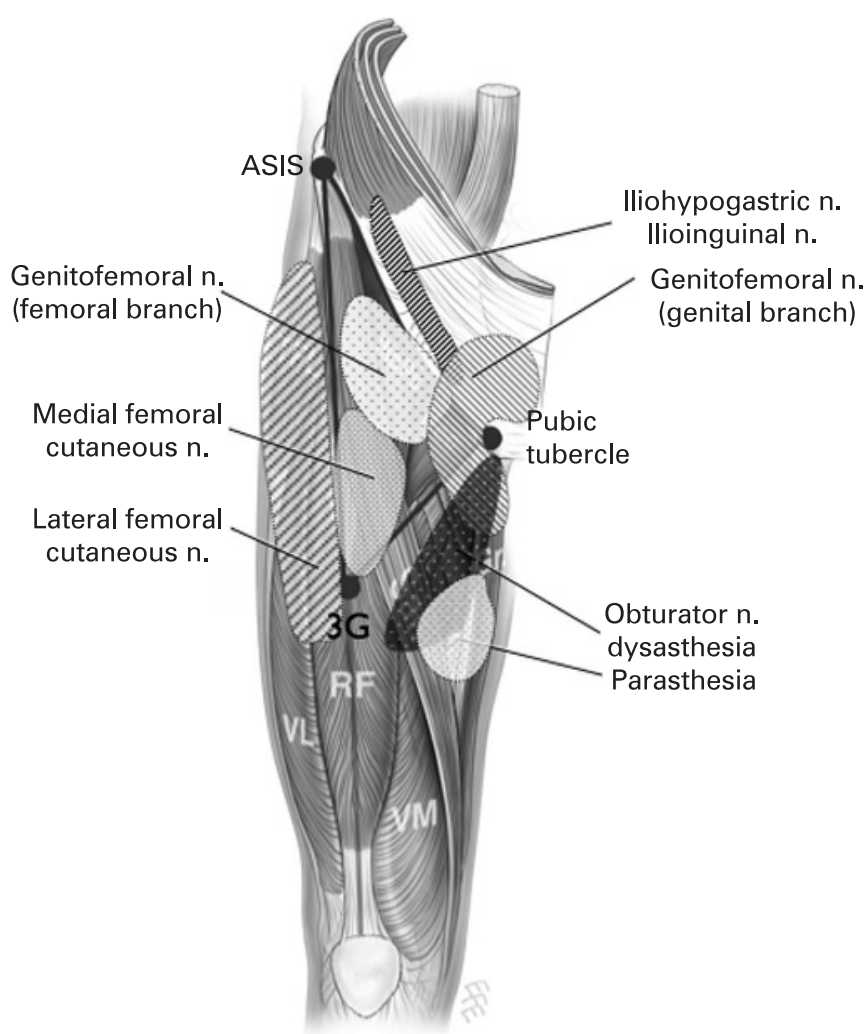

Figure 2 Neuropathy of the proximal lower limb. ASIS, anterior superior liac spine; $\mathrm{Gr}$, gracilis; $\mathrm{RF}$, rectus femoris; $3 \mathrm{G}$, the $3 \mathrm{G}$ point; $\mathrm{VL}$, vastus lateralis; VM, vastus medialis.

\section{Medial border of the groin triangle}

The line from the pubic tubercle to the $3 G$ point inferiorly forms the medial border of the triangle. Although neither the medial or lateral borders of the triangle comprise a muscular line, in both instances they work to separate the clinically important "groups" of structures that lie on either side of them. Medial to the border lie the adductor muscles, from superficial to deep-adductor longus, gracilis, adductor brevis, adductor magnus.

The adductor longus and gracilis tendons are the most commonly affected and lie in an almost continuous site of origin along the body of the pubis. The other adductor muscles (brevis and magnus) arise more posterolaterally along the inferior pubic ramus. The ramus forms a direct continuum between the pubic body and the ischial tuberosity. The obturator nerve divides in the obturator canal $(2-3 \mathrm{~cm}$ long canal situated in the anterosuperior aspect of the obturator foramen containing the obturator nerve, artery and vein) to anterior and posterior divisions. The anterior branch innervates the adductor longus, brevis, gracilis and, occasionally, the pectineus; it supplies sensory innervation to the skin and fascia of the inner distal thirds of the medial thigh. ${ }^{8}$

\section{Lateral border of triangle}

The line from the ASIS superiorly to the 3G point forms the lateral border of the triangle: femoro-acetabular joint; trochanteric bursa; tensor fasciae latae and iliotibial band.

Although the surface marking of the femora-acetabular joint lies within the triangle, the pathology of the joint is usually referred to as the greater trochanter, as such it is considered in this section. Gluteal bursae underlie the gluteus maximus and 
Table 1 Patho-anatomical approach: pubic tubercle region (diagnoses appear in order of frequency in an athletic population)

\begin{tabular}{|c|c|c|c|c|}
\hline Define and align & Pathology & Listen and localise & Palpate and re-create & Alleviate and investigate \\
\hline \multirow[t]{10}{*}{ Pubic tubercle } & Adductor tendon enthesopathy & $\begin{array}{l}\text { Insidious onset, warms up with } \\
\text { exercise }\end{array}$ & $\begin{array}{l}\text { Guarding on passive abduction, } \\
\text { weakness. } \\
\text { we Pubic "clock": } 6-8\end{array}$ & Magnetic resonance imaging ${ }^{11}$ \\
\hline & Rectus abdominis enthesopathy & $\begin{array}{l}\text { Well localised to insertion, acute or } \\
\text { insidious onset }\end{array}$ & $\begin{array}{l}\text { Pain from resisted sit-up. }{ }^{10} \text { Pubic "clock": } \\
12\end{array}$ & Magnetic resonance imaging ${ }^{11}$ \\
\hline & Pubic bone stress injury & $\begin{array}{l}\text { Non-specific diminished athletic } \\
\text { performance, loss of propulsive power }\end{array}$ & $\begin{array}{l}\text { Bone tenderness predominates }{ }^{1213} \\
\text { Diagnosis of exclusion }\end{array}$ & $\begin{array}{l}\text { Plain film, }{ }^{13} \text { magnetic resonance } \\
\text { imaging }^{14}\end{array}$ \\
\hline & Degenerative pubic symphysis & $\begin{array}{l}\text { Central pain, associated with stress } \\
\text { through symphysis - stair climbing }\end{array}$ & Tender over symphysis. Pubic "clock": 3 & $\begin{array}{l}\text { Plain film, stress view, }{ }^{15} \text { magnetic } \\
\text { resonance imaging }{ }^{14}\end{array}$ \\
\hline & $\begin{array}{l}\text { Incipient hernia; conjoint tendon } \\
\text { tear }\end{array}$ & $\begin{array}{l}\text { Insidious onset, diminished } \\
\text { performance, warms up }\end{array}$ & $\begin{array}{l}\text { Pain on resisted "torsion" of trunk } \\
\text { "ipsilateral direction". }{ }^{16} \text { Pubic "clock": } 11\end{array}$ & Ultrasound $^{17}$ \\
\hline & \multirow[t]{3}{*}{$\begin{array}{l}\text { Incipient hernia; external oblique } \\
\text { aponeurosis tear }\end{array}$} & \multirow[t]{3}{*}{$\begin{array}{l}\text { Acute onset, related to sport-specific } \\
\text { movement eg, "slap shot". }{ }^{22}\end{array}$} & $\begin{array}{l}\text { Pain on resisted "torsion" of trunk } \\
\text { "contralateral direction". }{ }^{16}\end{array}$ & Magnetic resosnance imaging ${ }^{18}$ \\
\hline & & & $\begin{array}{l}\text { Tenderness and dilation of superficial } \\
\text { inguinal ring on invagination of scrotum. }\end{array}$ & $\begin{array}{l}\text { Confirmation by direct vision at } \\
\text { arthroscopy }{ }^{19-21}\end{array}$ \\
\hline & & & Pubic "clock": 12-1 & \\
\hline & $\begin{array}{l}\text { Nerve entrapment; ilioinguinal } \\
\text { nerve }\end{array}$ & Altered skin sensation & $\begin{array}{l}\text { Superficial pain with or without hyper/ } \\
\text { dysaesthesia to skin over pubis. }{ }^{26}\end{array}$ & $\begin{array}{l}\text { Relief of pain by ultrasound-guided } \\
\text { local anaesthetic infiltration }{ }^{27}\end{array}$ \\
\hline & $\begin{array}{l}\text { Genitofemoral nerve (genital } \\
\text { branch) }\end{array}$ & Post inguinal surgery ${ }^{24}$ & Absence of muscular component ${ }^{26}$ & Nerve conduction studies ${ }^{7}$ \\
\hline
\end{tabular}

gluteus medius tendons proximal to their insertions. The iliotibial band or tract is a lateral thickening of the fasciae latae in the thigh. Proximally it splits into superficial and deep layers, enclosing tensor fasciae latae and anchoring this muscle to the iliac crest.

\section{Within the triangle}

Within the triangle the following structures are encountered: conjoint tendon of the iliopsoas muscle; rectus femoris muscle; femoral canal.

The psoas arises as a series of slips, each of which arise from the adjacent margins of the vertebral bodies and the intervening discs from the lower border of T12 to the upper border of L5. The iliacus arises from the upper two-thirds of the concavity of the iliac fossa and the inner lip of the iliac crest, as well as the ventral sacro-iliac and iliolumbar ligaments and the upper surface of the lateral part of the sacrum. The two muscles converge and pass downwards and medially beneath the inguinal ligament over the hip joint and into the lesser trochanter of the femur. The passage of this conjoined tendon over the hip joint is facilitated by the iliopsoas bursa, which is in some cases in direct communication with the hip joint. The rectus femoris arises via a direct head from the anterior inferior iliac spine and a reflected head arising from the superior acetabular rim and joint capsule. The femoral ring is the base of the femoral canal. Its surface marking is medial to the femoral artery, palpable at the mid-inguinal point. The femoral ring is bounded in front by the inguinal ligament, behind by the pectineus, medially by the crescentic base of the lacunar ligament and laterally by the fibrous septum on the medial side of the femoral vein.

\section{Nerve entrapment}

The classic distribution of the cutaneous innervation of the area incorporated in the triangle and their potential neuropathies is shown in fig 2; these, however, must serve as a guide only, as in vivo considerable variation occurs. ${ }^{76}$ 28-30 The clinician will appreciate that in addition to paraesthesias, a compressed nerve can give rise to pain. The additional possibility of referred or radicular pain from T12, L1, L2 and L3 must also be considered.

Table 2 Patho-anatomical approach: medial to the groin triangle (diagnoses appear in order of frequency in an athletic population)

\begin{tabular}{|c|c|c|c|c|}
\hline Define and align & Pathology & Listen and localise & Palpate and re-create & Alleviate and investigate \\
\hline \multirow[t]{9}{*}{ Medial to triangle } & Adductor/gracilis enthesopathy & $\begin{array}{l}\text { Insidious onset, diminished } \\
\text { performance, warms up }\end{array}$ & $\begin{array}{l}\text { Proximal adductor pain, at enthesis. } \\
\text { Guarding, weakness }{ }^{910}\end{array}$ & Magnetic resonance imaging ${ }^{11}$ \\
\hline & $\begin{array}{l}\text { Adductor longus pathology at } \\
\text { musculotendinous junction }\end{array}$ & Acute onset, worse during exercise & $\begin{array}{l}\text { Pain in proximal adductor }{ }^{10} \\
\text { (2-4 cm distal to enthesis), guarding, } \\
\text { weakness }^{910}\end{array}$ & Magnetic resonance imaging ${ }^{11}$ \\
\hline & Pubic bone stress injury & $\begin{array}{l}\text { Pain primarily at pubis radiating to } \\
\text { proximal thigh }\end{array}$ & $\begin{array}{l}\text { Bone tenderness, lack of point } \\
\text { muscular tenderness }\end{array}$ & Magnetic resonance imaging ${ }^{1131}$ \\
\hline & Stress fracture inferior pubic ramus & Insidious onset, heavy training load & $\begin{array}{l}\text { Hop test, }{ }^{32} \text { associated deep buttock } \\
\text { pain }\end{array}$ & $\begin{array}{l}\text { Plain } x \text { ray, magnetic resonance } \\
\text { imaging }^{33}\end{array}$ \\
\hline & Nerve entrapment & \multirow[t]{2}{*}{$\begin{array}{l}\text { Claudicant-type pain of medial thigh, } \\
\text { which settles on resting }\end{array}$} & \multirow{2}{*}{$\begin{array}{l}\text { Exercise-related adductor weakness, } \\
\text { superficial dysesthesia of mid-medial } \\
\text { thigh }^{35}\end{array}$} & $\begin{array}{l}\text { Electromyography of adductor } \\
\text { longus }^{36}\end{array}$ \\
\hline & I. Obturator nerve & & & $\begin{array}{l}\text { Guided local anaesthetic injection } \\
\text { to obturator foramen }\end{array}$ \\
\hline & II. Ilioinguinal nerve & Altered skin sensation & \multirow{2}{*}{$\begin{array}{l}\text { Dysaesthesia/hyperaesthesia over } \\
\text { area of skin supplied by nerve in } \\
\text { question }{ }^{24} 25\end{array}$} & $\begin{array}{l}\text { Relief of pain by ultrasound-guided } \\
\text { local anaesthetic infiltration }{ }^{27}\end{array}$ \\
\hline & $\begin{array}{l}\text { III. Genitofemoral nerve (genital } \\
\text { branch) }\end{array}$ & Post inguinal surgery? & & Nerve conduction studies ${ }^{7}$ \\
\hline & External iliac artery endofibrosis & $\begin{array}{l}\text { Thigh discomfort post high-intensity } \\
\text { exercise mainly in cyclists }\end{array}$ & $\begin{array}{l}\text { Exercise-related lower limb } \\
\text { weakness, exercise-altered bruit and } \\
\text { ankle/brachial index }\end{array}$ & $\begin{array}{l}\text { Doppler ultrasound }{ }^{39} \\
\text { Angiography }^{40}\end{array}$ \\
\hline
\end{tabular}


Table 3 Patho-anatomical approach: superior to the groin triangle (diagnoses appear in order of frequency in an athletic population)

\begin{tabular}{|c|c|c|c|c|}
\hline Define and align & Pathology & Listen and localise & Palpate and re-create & Alleviate and investigate \\
\hline \multirow[t]{10}{*}{ Superior to base } & Rectus abdominis tendinopathy & $\begin{array}{l}\text { Well localised to insertion, acute or } \\
\text { insidious onset }\end{array}$ & $\begin{array}{l}\text { Pain from resisted sit-up. }{ }^{1041} \text { Pubic } \\
\text { "clock": } 12\end{array}$ & Magnetic resonance imaging ${ }^{11}$ \\
\hline & $\begin{array}{l}\text { Incipient hernia; conjoint tendon } \\
\text { tear }\end{array}$ & $\begin{array}{l}\text { Insidious onset, diminished } \\
\text { performance, warms up }\end{array}$ & $\begin{array}{l}\text { Pain on resisted "torsion" of trunk } \\
\text { "ipsilateral direction". }{ }^{16} \text { Pubic "clock": } \\
11\end{array}$ & Ultrasound ${ }^{17}$ \\
\hline & \multirow[t]{3}{*}{$\begin{array}{l}\text { Incipient hernia; external oblique } \\
\text { aponeurosis tear }\end{array}$} & \multirow[t]{3}{*}{$\begin{array}{l}\text { Acute onset, related to sport-specific } \\
\text { movement, eg, "slap shot"22 }\end{array}$} & $\begin{array}{l}\text { Pain on resisted "torsion" of trunk } \\
\text { "contralateral direction"16 }\end{array}$ & Magnetic resonance imaging ${ }^{18}$ \\
\hline & & & $\begin{array}{l}\text { Tenderness and dilation of superficial } \\
\text { inguinal ring on invagination of } \\
\text { scrotum }^{23}\end{array}$ & \multirow[t]{2}{*}{$\begin{array}{l}\text { Confirmation by direct vision at } \\
\text { arthroscopy }^{19-21}\end{array}$} \\
\hline & & & Pubic "clock": 12-1 & \\
\hline & Inguinal hernia & Pain on valsalva manoeuvre & $\begin{array}{l}\text { Cough impulse, palpable mass at deep } \\
\text { inguinal ring (direct), in inguinal canal/ } \\
\text { scrotum (indirect) }\end{array}$ & $\begin{array}{l}\text { Ultrasound }{ }^{17} \\
\text { Herniography, }{ }^{42} \text { laparoscopy }\end{array}$ \\
\hline & $\begin{array}{l}\text { Nerve entrapment } \\
\text { llioinguinal nerve }\end{array}$ & \multirow[t]{4}{*}{ Altered skin sensation } & \multirow[t]{4}{*}{$\begin{array}{l}\text { Dysaesthesia/hyperaesthesia over area } \\
\text { of skin supplied by nerve in question }{ }^{726}\end{array}$} & $\begin{array}{l}\text { Relief of pain by ultrasound- } \\
\text { guided local anaesthetic } \\
\text { infiltration }^{27}\end{array}$ \\
\hline & Iliohypogastric nerve & & & \multirow[t]{3}{*}{ Nerve conduction studies ${ }^{7}$} \\
\hline & $\begin{array}{l}\text { Genitofemoral nerve (genital } \\
\text { branch) }\end{array}$ & & & \\
\hline & Lateral femoral cutaneous nerve & & & \\
\hline
\end{tabular}

\section{A PATHO-ANATOMICAL APPROACH USING THE GROIN TRIANGLE}

The diagnostic process of history and examination is often abbreviated. There is a growing tendency to rely on investigational studies as the initial diagnostic step (eg, proceeding to magnetic resonance imaging of a painful groin in the absence of a clear differential diagnosis). The authors propose a four-step approach to the diagnostic process emphasising history and examination and limiting investigation to the final step as follows.

\section{Step 1: define and align}

Define the anatomical points and borders of the triangle on the patient (ASIS, pubic tubercle and 3G point).

\section{Step 2: listen and localise}

Listen to the patient's history and obtain as many localising factors as possible, then pinpoint the pain in relation to the groin triangle.

\section{Step 3: palpate and re-create}

Carefully palpate the identified area and determine which anatomical structures are painful. The use of provocative manoeuvres/examinations (eg, exercise) to re-create the patient's pain can be a critical diagnostic step. To describe all of the manoeuvres in detail is beyond the scope of this text; readers are referred to reviews on this topic. ${ }^{32} 43$

\section{Step 4: alleviate and investigate}

When a number of anatomical structures are in close proximity, clinical presentations can be very similar. The manner in which pain can be removed may be very helpful. A decrease in pain following abstinence from aggravating activity is revealing. If a distinct structure can be identified, the elimination of symptoms following guided injection of local anaesthetic into the structure is invaluable. The authors recognise that a number of conditions discussed in this text may only be diagnosed definitively following radiological investigation; in these instances the most discriminative, evidence-based investigation is recommended.

\section{SPECIFIC SCENARIOS USING A PROBLEM-ORIENTED APPROACH}

The diagnostic stepwise approach using the groin triangle is summarised in tables $1-5$. The triangle is used to localise the pathology to a particular area. We refer the reader to the specific table relating to that border of the triangle. This provides a differential diagnosis and clarifies the most discriminative evidence-based tests.

Table 4 Patho-anatomical approach: lateral to the groin triangle (diagnoses appear in order of frequency in an athletic population)

\begin{tabular}{|c|c|c|c|c|}
\hline Define and align & Pathology & Listen and localise & Palpate and re-create & Alleviate and investigate \\
\hline \multirow[t]{6}{*}{ Lateral to triangle } & $\begin{array}{l}\text { Impingement/labral pathology, femoro- } \\
\text { acetabular joint }\end{array}$ & $\begin{array}{l}\text { Mechanical signs, clicking in joint } \\
\text { and/or catching }\end{array}$ & Impingement test ${ }^{44}$ & $\begin{array}{l}\text { Magnetic resonance imaging, } \\
\text { arthrogram }^{45}\end{array}$ \\
\hline & \multirow[t]{2}{*}{$\begin{array}{l}\text { Osteoarthritis/chondral damage, } \\
\text { femoro-acetabular joint }\end{array}$} & $\begin{array}{l}\text { History of traumatic/congenital } \\
\text { insult. Older age group }\end{array}$ & $\begin{array}{l}\text { Limited range of movement, }{ }^{46} \text { pain on } \\
\text { weight bearing }\end{array}$ & $\begin{array}{l}\text { Plain film } x \text { ray, magnetic } \\
\text { resonance imaging }\end{array}$ \\
\hline & & $\begin{array}{l}\text { Persistent lateral hip pain worse } \\
\text { on lying on affected side }\end{array}$ & $\begin{array}{l}\text { Pain on transition between lying/ } \\
\text { standing }^{47}\end{array}$ & $\begin{array}{l}\text { Ultrasound } .^{48} \text { Relief of pain by } \\
\text { ultrasound-guided local } \\
\text { anaesthetic injection }\end{array}$ \\
\hline & Iliotibial band friction syndrome & $\begin{array}{l}\text { External "snapping" and/or lateral } \\
\text { knee pain }\end{array}$ & $\begin{array}{l}\text { Re-create snapping } \\
\text { Ober's test }^{32}\end{array}$ & Ultrasound ${ }^{48}$ \\
\hline & Stress fracture neck of femur & $\begin{array}{l}\text { Heavy training load, } \\
\text { biomechanical/gait abnormality }\end{array}$ & Hop test, ${ }^{50}$ fulcrum test ${ }^{51}$ & $\begin{array}{l}\text { Plain film } x \text { ray, Magnetic } \\
\text { resonance imaging }\end{array}$ \\
\hline & $\begin{array}{l}\text { Nerve entrapment; lateral cutaneous } \\
\text { femoral nerve/meralgia paraesthetica }\end{array}$ & Exercise induced, obesity ${ }^{52}$ & $\begin{array}{l}\text { Reproduction of symptoms on pressure } \\
\text { inferior to anterior superior iliac spine }\end{array}$ & Nerve conduction studies ${ }^{7}$ \\
\hline
\end{tabular}


Table 5 Patho-anatomical approach: within the groin triangle (diagnoses appear in order of frequency in an athletic population)

\begin{tabular}{|c|c|c|c|c|}
\hline Define and align & Pathology & Listen and localise & Palpate and re-create & Alleviate and investigate \\
\hline \multirow[t]{5}{*}{ Within the triangle } & \multirow[t]{2}{*}{ Iliopsoas syndrome } & \multirow[t]{2}{*}{$\begin{array}{l}\text { Pain above and below inguinal } \\
\text { ligament-associated snapping at } \\
\text { hip joint }\end{array}$} & \multirow[t]{2}{*}{ Thomas test, modified ${ }^{32}$} & $\begin{array}{l}\text { Ultrasound scan dynamic view of } \\
\text { snapping }{ }^{48} \text { with or without } \\
\text { injection }^{53}\end{array}$ \\
\hline & & & & Magnetic resonance imaging \\
\hline & $\begin{array}{l}\text { Rectus femoris tendinopathy/ } \\
\text { apophysitis }\end{array}$ & Does knee movement affect pain? & Rectus femoris contracture test ${ }^{54}$ & $\begin{array}{l}\text { Plain } x \text { ray, ultrasound } s^{48}{ }^{48} \\
\text { Magnetic resonance imaging }\end{array}$ \\
\hline & Femoral hernia & $\begin{array}{l}\text { Painful lump inferomedial to pubic } \\
\text { tubercle }\end{array}$ & Minimal relationship to exercise & $\begin{array}{l}\text { Ultrasound } \text { scan }^{17} \\
\text { Herniography }\end{array}$ \\
\hline & $\begin{array}{l}\text { Nerve entrapment } \\
\text { Genitofemoral nerve (femoral branch) } \\
\text { Medial femoral cutaneous nerve }\end{array}$ & Altered skin sensation & $\begin{array}{l}\text { Dysaesthesia/hyperaesthesia over } \\
\text { area of skin supplied by nerve in } \\
\text { question }\end{array}$ & $\begin{array}{l}\text { Relief of pain by local anaesthetic } \\
\text { infiltration }^{27} \\
\text { Nerve conduction studies }\end{array}$ \\
\hline
\end{tabular}

\section{PUBIC TUBERCLE}

Because many potentially anatomical structures converge at this point, we propose a marking of the structure in similar fashion to a clock face (fig 3, table 1). This schematic representation of the anatomy of the area serves as a guide to what may be palpable following invagination of the scrotum. The examining clinician can therefore "walk their finger" around the tubercle assigning each part of the clock face to the relevant attachment as highlighted in fig 3 . The authors recognise the variability of structures in this area, having based diagrams on cadaveric studies performed prior to this paper. ${ }^{55}$ We have employed the term "pubic bone stress injury" for what is often in the literature called "osteitis pubis". We feel this is a better reflection of the clinical picture in the absence of any evidence of an inflammatory process.

The topic of incipient hernia is included as disorders of the posterior and anterior inguinal walls. These are diagnoses of exclusion and, outside of the most experienced hands, probably inseparable. These may represent different ends of a spectrum of pathology in the area as a result of differing sporting activity. ${ }^{3} 19222356$

\section{MEDIAL TO THE TRIANGLE}

Adductor longus pathology is the most common cause of pain in this area; differentiation of enthesis-related problems from those at the musculitendinous junction is important. The abnormal mechanics that arise as a result of adductor dysfunction play a critical role in the generation of a chronic pain/dysfunction cycle in the area (fig 4, table 2).

\section{SUPERIOR TO THE TRIANGLE}

Rectus abdominis pathology tends to be well localised to its insertion at the pubic tubercle, often making it the most clearcut diagnosis in this area. This may arise as a primary diagnosis, or develop secondary to pubic overload originating from adductor or iliopsoas pathology (fig 5, table 3).

\section{LATERAL TO THE TRIANGLE}

As a cause of recalcitrant groin pain, pathology of the femoroacetabular joint should not be underestimated. The joint is prone to degenerative, inflammatory and infective processes. The long-term contribution of acute or repetitive trauma to the

Figure 3 The pubic clock.

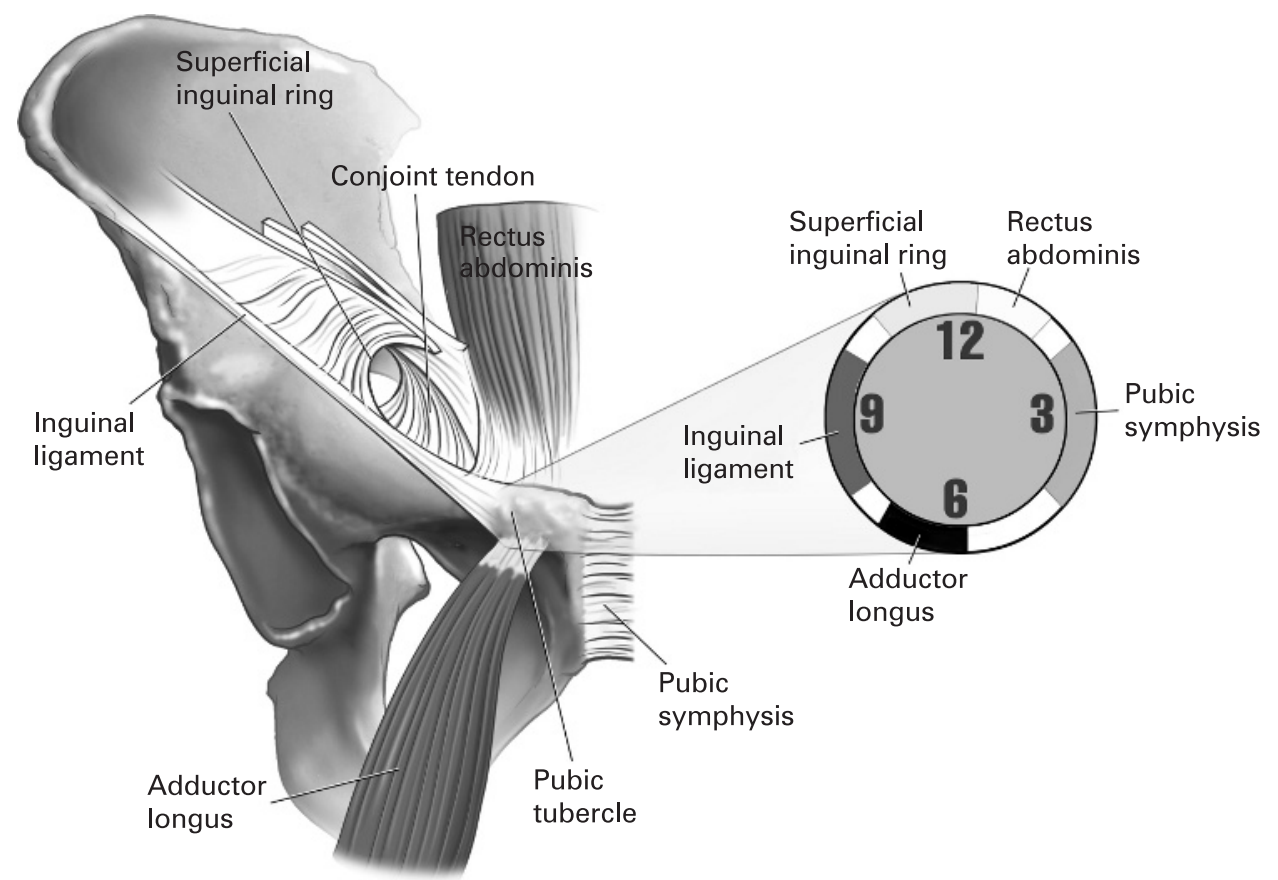




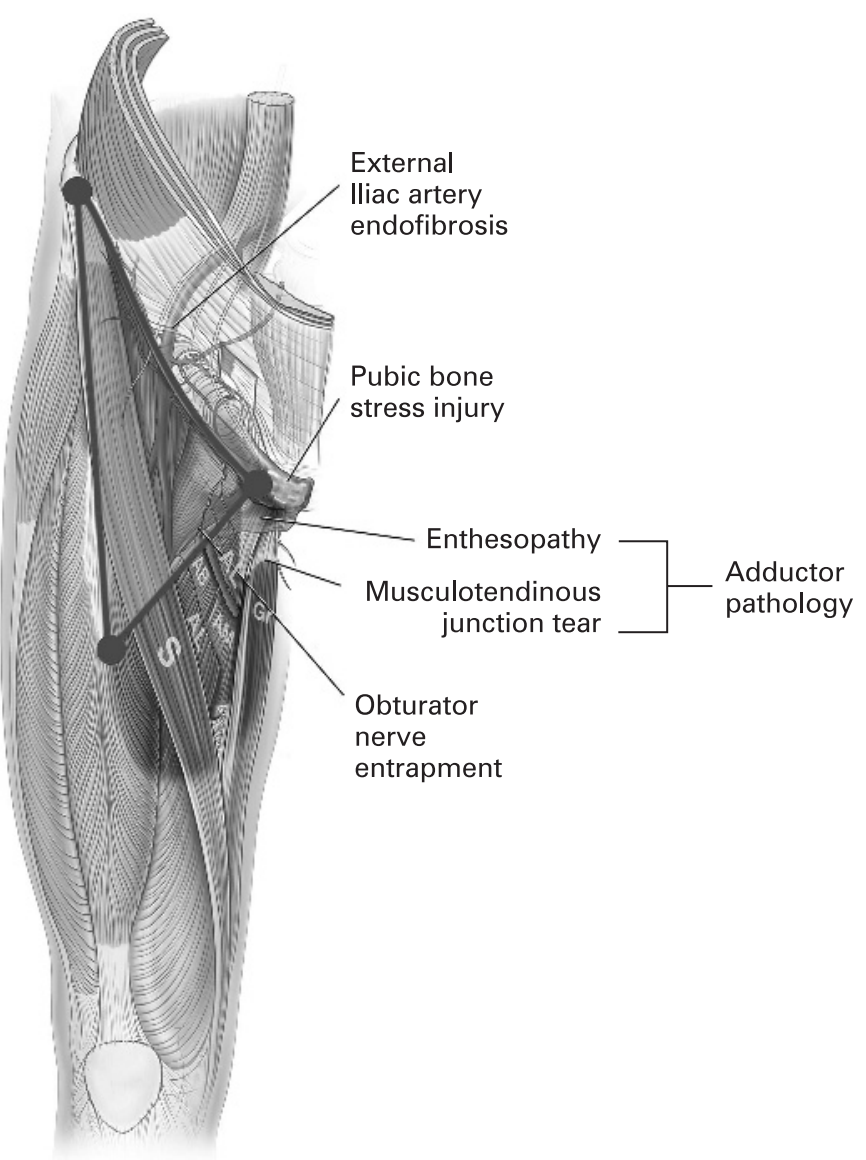

Figure 4 Medial to the triangle. $A B$, adductor brevis; $A L$, adductor longus; $A M$, adductor magnus; $G r$, gracilis; $S$, sartorius.

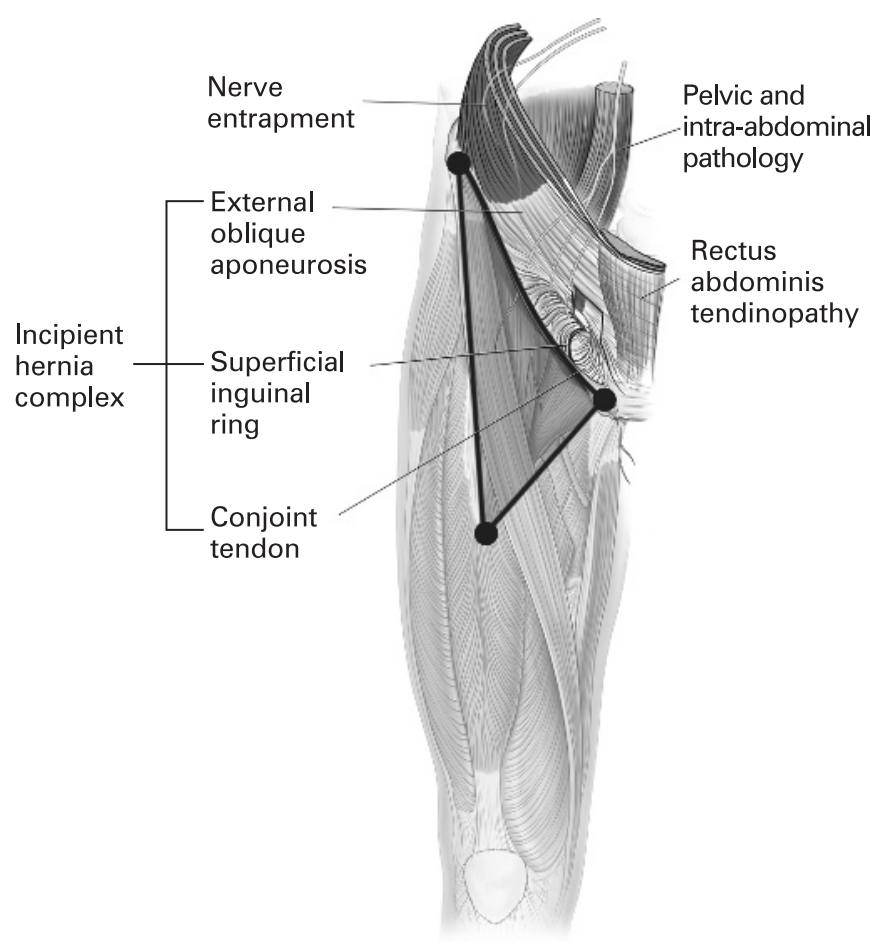

Figure 5 Superior to the triangle.

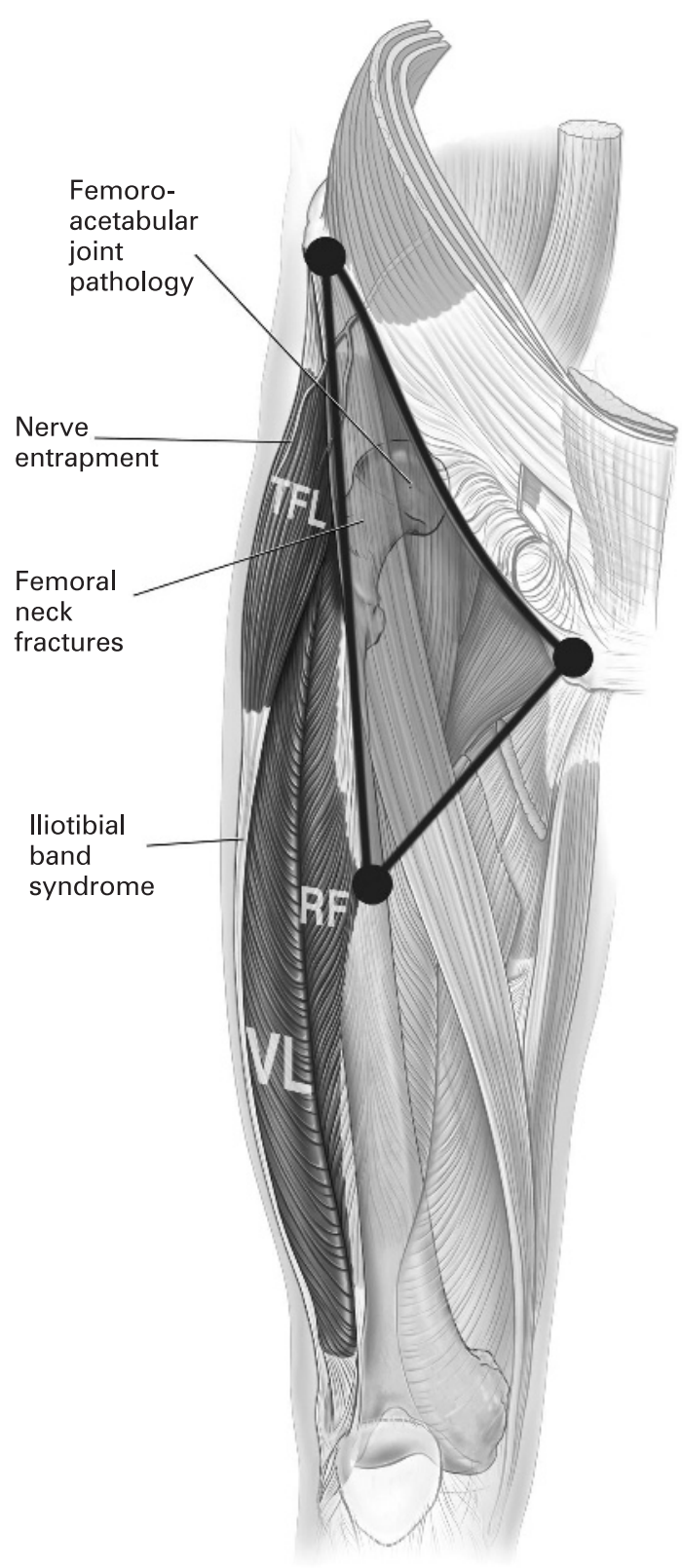

Figure 6 Lateral to the triangle. RF, rectus femoris; TFL, tensor fasciae latae; VL, vastus lateralis.

development of degenerative conditions such as osteoarthritis is of particular concern in the sports setting (fig 6, table 4).

\section{WITHIN THE TRIANGLE}

Pathology of the iliopsoas muscle may cause pain that is referred in the area superior to the triangle, but the conjoint tendon is the most palpable structure within the triangle when the hip is flexed. This is a common, although underdiagnosed, cause of groin pain. ${ }^{57}$ It is particularly prone to irritation when overloaded secondary to dysfunction of other muscular structures around the groin, such as the adductors (fig 7 , table 5).

\section{INTRA-ABDOMINAL PATHOLOGY}

Discussion of this topic is beyond the scope of this paper; gastrointestinal and genitourinary pathology may mask as groin discomfort or pain. Key discriminating symptoms may be signs of systemic illness, systemic inflammatory response and no 


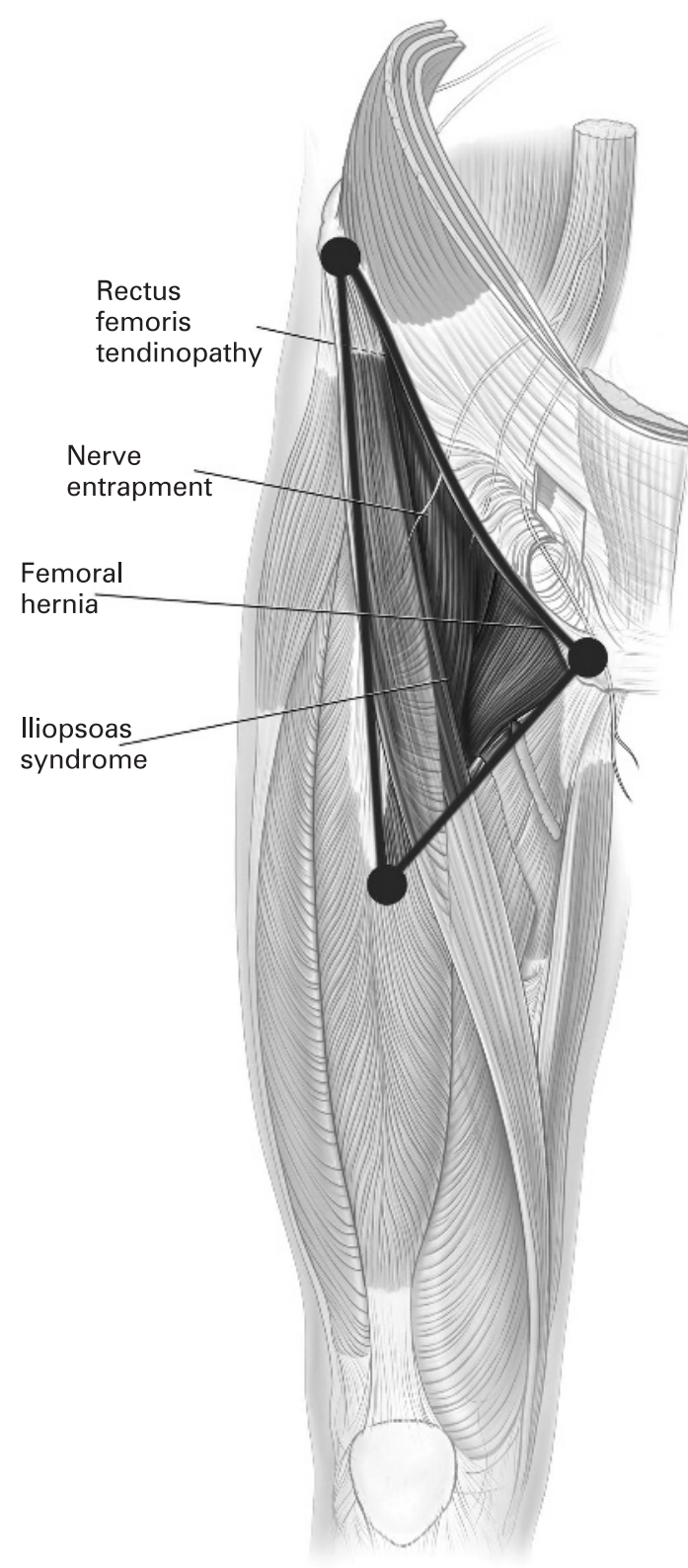

Figure 7 Within the triangle.

correlation between exercise and symptoms or signs. Any or all of the above in conjunction with a negative musculoskeletal examination serve to alert the examining physician to focus their examinations beyond the musculoskeletal system.

\section{CONCLUSION}

This paper presents a method of teaching the causes of chronic groin pain. By offering a systematic means of limiting the differential diagnosis through history examination, diagnostic manoeuvres and, when necessary, directed investigation, this method may help the less experienced clinician with the diagnostic process.

The groin triangle is one section of the "3G" approach to teaching the causes of chronic pain in the proximal lower limb. This paper should therefore be read in conjunction with the gluteal and greater trochanter triangle papers to address the three-dimensional nature of the region fully.

\section{What this paper adds}

- This paper outlines a novel educational approach to the categorisation of pathologies in the groin area in an athlete.

- Pain-generating structures are categorised according to their anatomical position, around a triangle based on easily located anatomical landmarks.

- This categorisation, with accompanying high-quality diagrams, focuses the diagnostic process. Discriminative questioning and evidence-based examination presented in tabular form facilitate accurate differential diagnosis.

Experience and a thorough knowledge of the anatomy of the region remain vital in any complete understanding of groin pain. By providing a means of focusing the differential diagnosis in a structured manner, practitioners who lack expertise may approach this problem with more confidence.

Competing interests: None.

\section{REFERENCES}

1. Walden $\mathbf{M}$, Hagglund M, Ekstrand J. Football injuries during European Championships 2004-2005. Knee Surg Sports Traumatol Arthrosc 2007;

2. Orchard J, Seward H. Epidemiology of injuries in the Australian Football League, seasons 1997-2000. Br J Sports Med 2002;36:39-44.

3. Emery CA, Meeuwisse WH, Powell JW. Groin and abdominal strain injuries in the National Hockey League. Clin J Sport Med 1999;9:151-6.

4. Brooks JH, Fuller CW, Kemp SP, et al. Epidemiology of injuries in English professional rugby union: Part 2. Training injuries. Br J Sports Med 2005;39:767-75

5. Brooks JH, Fuller CW, Kemp SP, et al. Epidemiology of injuries in English professional rugby union: Part 1. Match injuries. Br J Sports Med 2005;39:757-66.

6. Koliyadan SV, Narayan G, Balasekran P. Surface marking of the deep inguinal ring. Clin Anat (NY) 2004:17:554-7.

7. Rab M, Ebmer And J, Dellon AL. Anatomic variability of the ilioinguinal and genitofemoral nerve: implications for the treatment of groin pain. Plastic Reconstruct Surg 2001;108:1618-23.

8. McCrory P, Bell S, Bradshaw C. Nerve entrapments of the lower leg, ankle and foot in sport. Sports Med (Auckland) 2002;32:371-91.

9. Kendall FP, McCreary E. ME, eds. Lower extremity muscles. In: Muscles - testing and function. Williams and Wilkins, 1983:158-79.

10. Holmich $\mathbf{P}$, Holmich LR, Bjerg AM. Clinical examination of athletes with groin pain: an intraobserver and interobserver reliability study. Br J Sports Med 2004;38:446-51.

11. Zoga AC, Kavanagh EC, Omar IM, et al. Athletic pubalgia and the "sports hernia": MR imaging findings. Radiology 2008;247:797-807.

12. Lynch SA, Renstrom PA. Groin injuries in sport: treatment strategies. Sports Med (Auckland) 1999;28:137-44.

13. Fricker PA, Taunton JE, Ammann W. Osteitis pubis in athletes. Infection, inflammation or injury? Sports Med (Auckland) 1991;12:266-79.

14. Lovell G, Galloway H, Hopkins W, et al. Osteitis pubis and assessment of bone marrow edema at the pubic symphysis with MRI in an elite junior male soccer squad. Clin J Sport Med 2006;16:117-22.

15. LaBan MM, Meerschaert JR, Taylor RS, et al. Symphyseal and sacroiliac joint pain associated with pubic symphysis instability. Arch Phys Med Rehabil 1978;59:470-2.

16. Kumar S. Ergonomics and biology of spinal rotation. Ergonomics 2004;47:370-415.

17. van den Berg JC, Rutten MJ, de Valois JC, et al. Masses and pain in the groin: a review of imaging findings. Eur Radiol 1998;8:911-21.

18. Nelson EN, Kassarjian A, Palmer WE. MR imaging of sports-related groin pain. Magnet Reson Imag Clin North Am 2005;13:727-42.

19. Kluin J, den Hoed PT, van Linschoten R, et al. Endoscopic evaluation and treatment of groin pain in the athlete. Am J Sports Med 2004;32:944-9.

20. Kumar A, Doran J, Batt ME, et al. Results of inguinal canal repair in athletes with sports hernia. J R Coll Surg (Edinburgh) 2002;47:561-5.

21. Steele $\mathbf{P}$, Annear $\mathbf{P}$, Grove JR. Surgery for posterior inguinal wall deficiency in athletes. J Sci Med Sport/Sports Med Aust 2004;7:415-21; discussion 22-3.

22. Irshad K, Feldman LS, Lavoie C, et al. Operative management of "hockey groin syndrome": 12 years of experience in National Hockey League players. Surgery 2001;130:759-64; discussion 64-6.

23. Gilmore J. Groin pain in the soccer athlete: fact, fiction, and treatment. Clin Sports Med 1998;17:787-93, vii.

24. Liszka TG, Dellon AL, Manson PN. lliohypogastric nerve entrapment following abdominoplasty. Plast Reconstruct Surg 1994;93:181-4.

25. Harms BA, DeHaas DR Jr, Starling JR. Diagnosis and management of genitofemoral neuralgia. Arch Surg 1984;119:339-41. 
26. Lee CH, Dellon AL. Surgical management of groin pain of neural origin. J Am Coll Surgeons 2000:191:137-42.

27. Eichenberger $\mathbf{U}$, Greher $\mathrm{M}$, Kirchmair $\mathrm{L}$, et al. Ultrasound-guided blocks of the ilioinguinal and iliohypogastric nerve: accuracy of a selective new technique confirmed by anatomical dissection. Br J Anaesth 2006;97:238-43.

28. Krahenbuhl L, Striffeler H, Baer HU, et al. Retroperitoneal endoscopic neurectomy for nerve entrapment after hernia repair. Br J Surg 1997:84:216-19.

29. Morikawa R. [Distribution and variations of the nerves deriving from the lumbar plexus and supplying the abdominal wall]. Kaibogaku Zasshi 1971;46:312-38.

30. Starling JR, Harms BA. Diagnosis and treatment of genitofemoral and ilioinguinal neuralgia. World J Surg 1989;13:586-91.

31. Verrall GM, Slavotinek JP, Barnes PG, et al. Assessment of physical examination and magnetic resonance imaging findings of hamstring injury as predictors for recurrent injury. J Orthopaed Sports Phys Ther 2006;36:215-24.

32. Malanga GA, Nadler SF. Physical examination of the hip. In: Musculoskeletal physical examination, an evidence-based approach. Philadelphia, PA: Elsevier Mosby, 2006:251-79.

33. Berger FH, de Jonge MC, Maas M. Stress fractures in the lower extremity. The importance of increasing awareness amongst radiologists. Eur J Radiol 2007;62:16-26.

34. Bradshaw C, McCrory P, Bell S, et al. Obturator nerve entrapment. A cause of groin pain in athletes. Am J Sports Med 1997;25:402-8.

35. Bradshaw C, McCrory P. Obturator nerve entrapment. Clin J Sport Med 1997:7:217-19.

36. Delagi E, Perotto A. Anatomic guide for the electromyographer, 2nd ed. Springfield: Charles C Thomas Publishers, 1980.

37. Magora F, Rozin R, Ben-Menachem $\mathrm{Y}$, et al. Obturator nerve block: an evaluation of technique. Br J Anaesth 1969;41:695-8.

38. Abraham $\mathbf{P}$, Bickert $\mathrm{S}$, Vielle $\mathrm{B}$, et al. Pressure measurements at rest and after heavy exercise to detect moderate arterial lesions in athletes. J Vasc Surg 2001:33:721-7.

39. Abraham P, Leftheriotis G, Bourre Y, et al. Echography of external iliac artery endofibrosis in cyclists. Am J Sports Med 1993;21:861-3.

40. Abraham P, Chevalier JM, Saumet JL. External iliac artery endofibrosis: a 40-year course. J Sports Med Phys Fitness 1997;37:297-300.

41. Meyers WC, Foley DP, Garrett WE, et al. Management of severe lower abdominal or inguinal pain in high-performance athletes. PAIN (Performing Athletes with Abdominal or Inguinal Neuromuscular Pain Study Group). Am J Sports Med 2000;28:2-8.
42. Garner JP, Patel S, Glaves J, et al. Is herniography useful? Hernia 2006:10:66-9.

43. Brukner PD, Khan KM. Clinical sports medicine, 3rd ed. Sydney: McGraw Hill, 2006

44. Ganz R, Parvizi J, Beck M, et al. Femoroacetabular impingement: a cause for osteoarthritis of the hip. Clin Orthopaed Relat Res 2003:417:112-20.

45. Leunig $\mathbf{M}$, Podeszwa $\mathrm{D}$, Beck $\mathbf{M}$, et al. Magnetic resonance arthrography of labral disorders in hips with dysplasia and impingement. Clin Orthopaed Relat Res 2004;418:74-80.

46. Birrell F, Croft $P$, Cooper $C$, et al. Predicting radiographic hip osteoarthritis from range of movement. Rheumatology (Oxford) 2001:40:506-12.

47. Bird PA, Oakley SP, Shnier R, et al. Prospective evaluation of magnetic resonance imaging and physical examination findings in patients with greater trochanteric pain syndrome. Arthritis Rheum 2001;44:2138-45.

48. Allen GM, Wilson DJ. Ultrasound in sports medicine-a critical evaluation. Eur J Radiol 2007:62:79-85.

49. Brignall CG, Brown RM, Stainsby GD. Fibrosis of the gluteus maximus as a cause of snapping hip. A case report. J Bone Joint Surg Am 1993:75:909-10.

50. Monteleone GP Jr. Stress fractures in the athlete. Orthoped Clin North Am 1995;26:423-32

51. Johnson AW, Weiss CB Jr, Wheeler DL. Stress fractures of the femoral shaft in athletes--more common than expected. A new clinical test. Am J Sports Med 1994;22:248-56.

52. Seror P, Seror R. Meralgia paresthetica: clinical and electrophysiological diagnosis in 120 cases. Muscle Nerve 2006;33:650-4.

53. Adler RS, Buly R, Ambrose R, et al. Diagnostic and therapeutic use of sonographyguided iliopsoas peritendinous injections. AJR Am J Roentgenol 2005;185:940-3.

54. Magee D. Orthopedic physical examination, 4th ed. Philedelphia: WB Saunders, 2002.

55. Franklin-Miller A, Falvey EC, McCrory $\mathrm{P}$, et al. Landmarks for the $3 \mathrm{G}$ approach groin, gluteal, and greater trochanter triangles, a pathoanatomical method in sports medicine. Eur J Anat 2008; in press.

56. Lovell G. The diagnosis of chronic groin pain in athletes: a review of 189 cases. Aust J Sci Med Sport 1995;27:76-9.

57. Holmich P. Long-standing groin pain in sportspeople falls into three primary patterns - a "clinical entity" approach: prospective study of 207 patients. Br J Sports Med 2007:41:247-52. 